\title{
EFFECTS OF CORTICOSTEROIDS ON THE RELEASE OF MEDIATORS IN ANAPHYLAXIS OF SENSITIZED GUINEA PIG TISSUES
}

\author{
Norio KURIHARA and Katsuhiro SHIBATA \\ Department of Pharmacology, School of Medicine, Gunma University, Maebashi, Japan
}

Accepted February 5, 1975

\begin{abstract}
Anaphylaxis was induced in vitro in the small intestine, lung, aorta and heart of activity sensitized guinea pigs by adding the antigen after immersion in $\mathrm{T} y$ rode solution, and relcased histaminc and 5-HT were spectrophotofluorometrically determined to investigate the effect of corticosteroids on the releases. Dexamethasone administration markedly reduced the release of histamine and 5-HT in anaphylaxis, but DOCA exerted no effect on the release of these mediators from the tissues. On the other hand, aldosterone significantly decreased the release of histanine from the tissues in anaphylaxis, but did not produce any reduction in the release of 5-HT.
\end{abstract}

The authors previously spectrophotofluorometrically determined the amount of mediators released from tissues of sensitized guinca pigs by addition of an antigen, and reported that while histamine was released on application of the antigen, 5-hydroxytryptamine (5-HT) was spontaneously released without antigen application (1). The purpose of the present experiment was to investigate the effect of corticosteroids on the release of the mediators from tissues of sensitized guinea pigs in anaphylaxis.

\section{MATERIALS AND METHODS}

Sixty adult male guinea pigs, weighing approx. $600 \mathrm{~g}$, were fed a solid diet (RC-4, Oriental Co., Japan), and given tap water ad libitam. The methods for detecting mediator release were similar to those previously described (1).

Active sensitization procedtres: The initial immunization was done by giving $1 \mathrm{ml}$ of a mixture of the same volumes of a $1 \% \mathrm{egg}$ albumin (Sigma Chemical Co., U.S.A.) saline solution and Freund's complete adjuvant (Difco Laboratory, U.S.A.) at 5 s.c. sites on the back and extremities of the animals. A month later, $2 \mathrm{ml}$ of $1 \%$ egg albumin in saline solution was given as a booster shot.

In vitro anaphylaxis: Seven days after the booster shot and a 24 he fast, the animals were decapitated following a blow on the head. Immediately the entire small intestine, lung, aorta and heart were removed, and after washing twice with Tyrode solution, were immersed in $20 \mathrm{ml}$ of this same solution. Anaphylaxis was induced when the tissues were incubated with $0.5 \mathrm{ml}$ of a $1 \%$ egg albumin in Tyrode solution at $37^{\circ} \mathrm{C}$ for $5 \mathrm{~min}$ in a water bath incubator. Immediately after this incubation, the tissues were taken out, and put in an oven at $80^{\circ} \mathrm{C}$ for $10 \mathrm{hr}$. The dry weights were then determined. Ten $\mathrm{ml}$ of the Tyrode solution used as an incubation medium, was put into ampoules, immediately lyo- 
philized, then stored in a deep freezer until the time of chemical assay.

Chemical assay: The assay was carried out within a week after preparation of the samples. Histamine was assayed by the method of Shore et al. (2), and 5-HT by that of Udenfriend et al. (3), both spectrophotofluorometrically. The results were expressed as free base in $九 g$ per $\mathrm{g}$ dry weight of the tissues, and given together with the standard error.

Corticoids used were dexamethasone (Dex) (Nippon Merck Banyu Co., Japan); aldosterone (Ald) (Sigma Chemical Co., U.S.A.); and desoxycorticosterone acetale (DOCA) (Takeda, Japan). Controls were given Aqueous Vehicle No. 1 (Merck), a 9.5\% alcohol saline solution and sesame oil, which are the solvents of the above mentioned three corticoids, respectively. DOCA and sesame oil was given i.m. into the femoral region, but the other agents were given s.c. on the back. Each experimental group included 5 animals. Doses of drugs and intervals between the injection and sacrifice are listed in Table 1.

TABLE 1. Experimental conditions

\begin{tabular}{|c|c|c|c|c|}
\hline Group & \multicolumn{3}{|c|}{$\begin{array}{l}\text { Dose and route of } \\
\text { administration }\end{array}$} & \multirow{2}{*}{$\begin{array}{c}\text { Interval between } \\
\text { injection and } \\
\text { sacrifice } \\
24 \mathrm{hr}\end{array}$} \\
\hline Control (Aq. vehicle No. 1) & & $\mathrm{kg} \times 1$ & s.c. & \\
\hline Dexamethasone & 0.005 & $\mathrm{~kg} \times 1$ & $"$ & $"$ \\
\hline " & 0.1 & $"$ & " & " \\
\hline " & 0.5 & $"$ & " & " \\
\hline $9.5 \%$ Alcohol saline & & $\mathrm{kg} \times 1$ & s.c. & $3 \mathrm{hr}$ \\
\hline Aldosterone & 0.01 & $\mathrm{~kg} \times 1$ & $"$ & " \\
\hline$"$ & 0.02 & " & $"$ & " \\
\hline " & 0.05 & " & " & $"$ \\
\hline Sesame oil & & $\mathrm{kg} \times \mathrm{I}$ & i.m. & $24 \mathrm{hr}$ \\
\hline DOCA & & $\mathrm{kg} \times 1$ & $"$ & $"$ \\
\hline Sesame oil & & $\mathrm{kg} \times 3$ & i.m. & $24 \mathrm{hr}$ \\
\hline DOCA & & $\mathrm{kg} \times 3$ & " & $"$ \\
\hline
\end{tabular}

\section{RESULTS}

I) Effects of dexamethasone on histamine and 5-HT relcase in anaphylaxis of sensitized tisstres

i) Histamine release: The amount of histamine release from the control small intestine, lung, aorta and heart in anaphylaxis was $0.23 \pm 0.04,0.98 \pm 0.12,6.29+1.51$ and $1.21 \pm 0.32 \mu \mathrm{g} / \mathrm{g}$, respectively. After Dex administration, all were reduced. In particular, after the administrations of $0.1 \mathrm{mg} / \mathrm{kg}$ and $0.5 \mathrm{mg} / \mathrm{kg}$, the release from the small intestine and lung was significantly decreased (Fig. 1).

ii) 5-HT release: The amount of 5-HT release in anaphylaxis from the control small intestine, lung, aorta and heart was $0.13 \pm 0.010 .05 \perp 0.01,0.87 \pm 0.38$ and $0.20 \pm$ $0.03 \mu \mathrm{g} / \mathrm{g}$, respectively. After Dex administration, the 5 -HT release from the small in- 


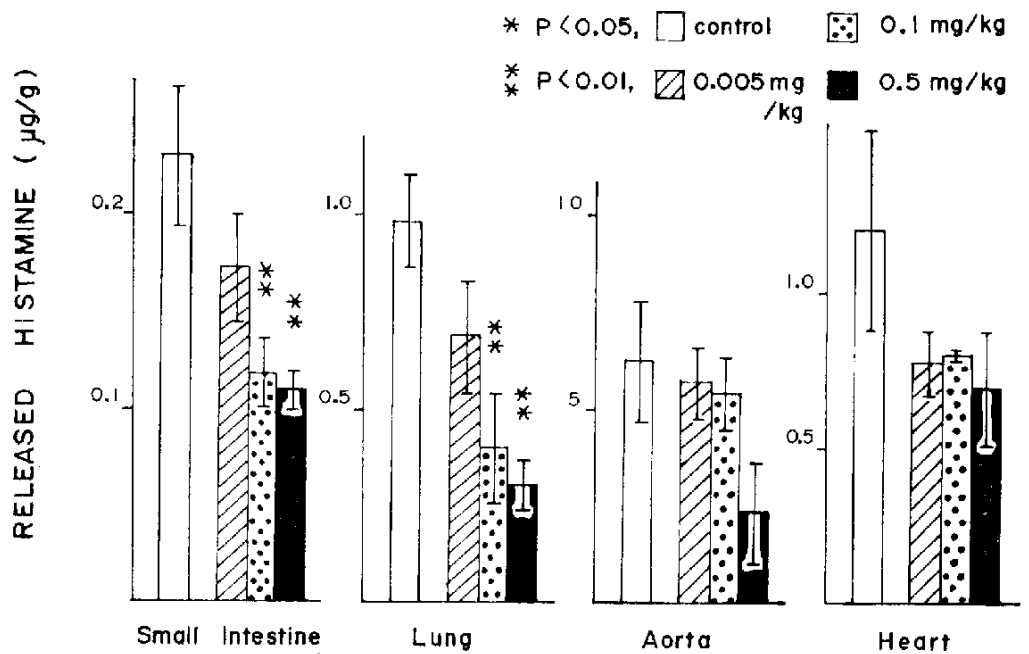

FiG. 1. Effect of dexamethasone on histamine release (Mean \pm S.E.) in anaphylaxis of sensitized tissues.

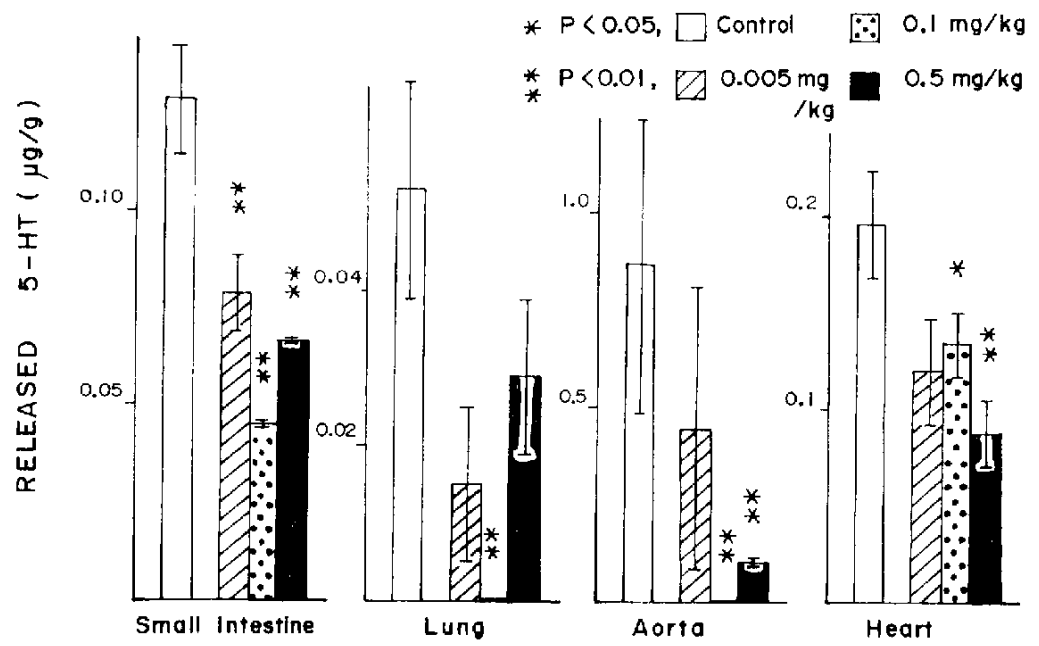

FIG. 2. Effect of dexamethasone on 5 -HT release (Mean \pm S.E.) in anaphylaxis of sensitized tissues.

testine in anaphylaxis was significantly reduced in all of three doses and release from other tissues was also significantly reduced, when $0.1 \mathrm{mg} / \mathrm{kg}$ was given. The amount of $5-\mathrm{HT}$ release in anaphylaxis from the aorta and heart was significantly reduced, when $0.5 \mathrm{mg} / \mathrm{kg}$ of Dex was given (Fig. 2).

2) Effects of aldosterone on histanine and 5-HT release in anaphylaxis of sensitized tissues

i) Histamine release: The amount of histamine release in anaphylaxis from the control small intestine, lung, aorta and heart was $0.22 \pm 0.01,1.03 \pm 0.11,4.52 \pm 0.27$ and $0.94 \pm$ $0.10 \mu \mathrm{g} / \mathrm{g}$, respectively. After Ald administration, histamine release from the small intestine in anaphylaxis was significantly decreased. Rclcase from the lung and heart was 


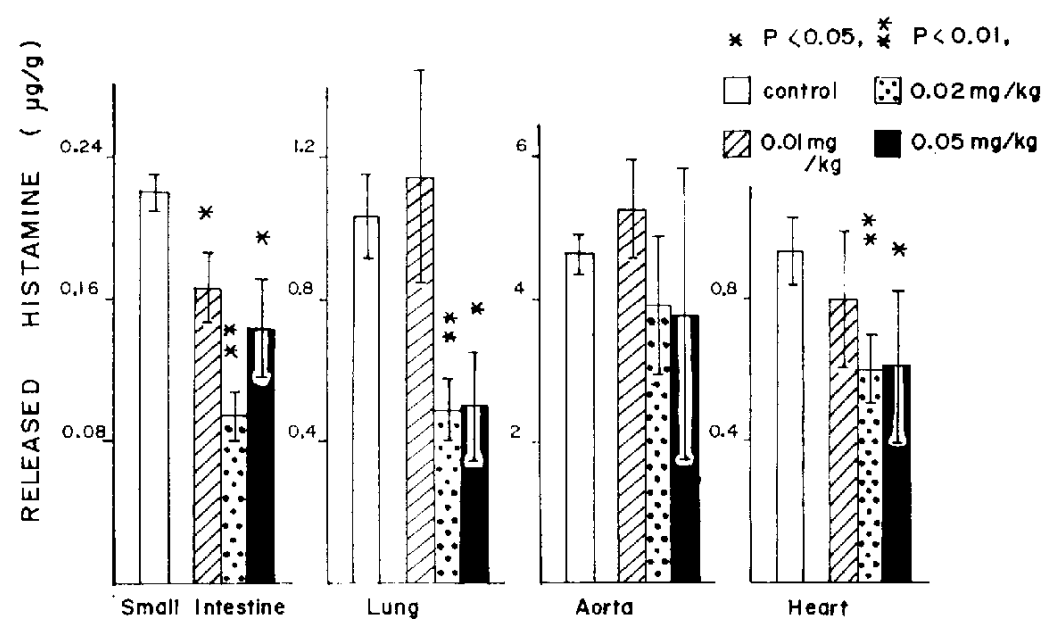

FIG. 3. Effect of aldosterone on histamine release (Mean \pm S.E.) in anaphylaxis of sensitized tissues.

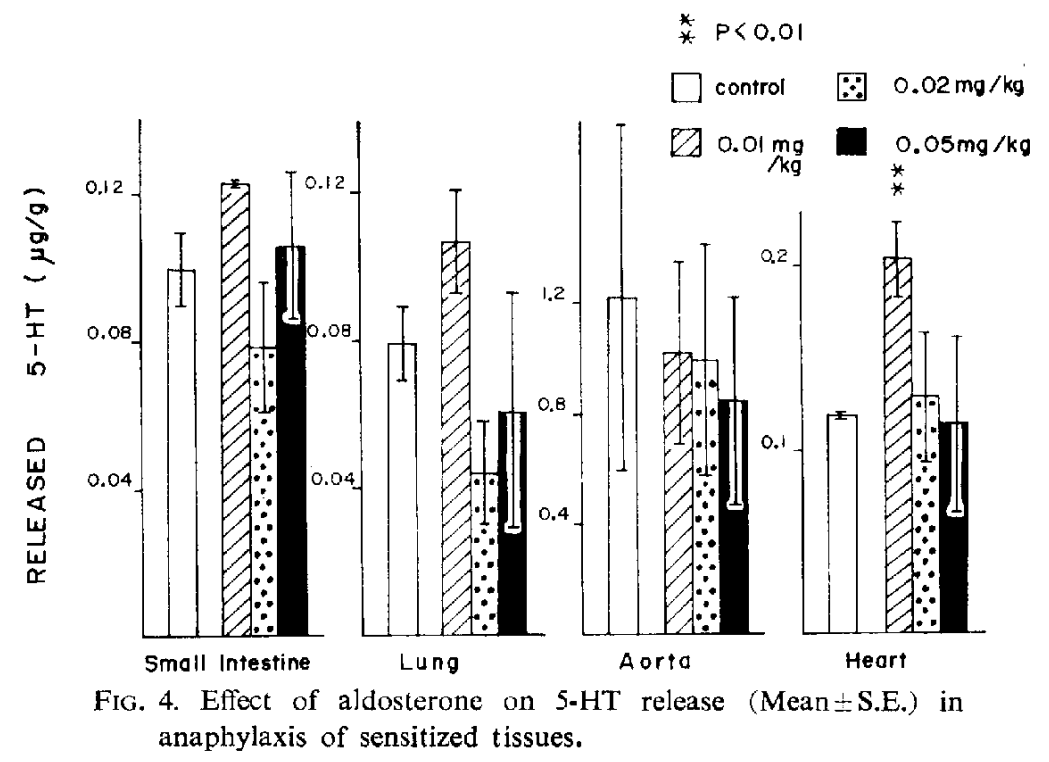

significantly decreased when $0.02 \mathrm{mg} / \mathrm{kg}$ or $0.05 \mathrm{mg} / \mathrm{kg}$ of Ald was given, but the release from the aorta revealed no difference from the control (Fig. 3).

ii) 5-HT release: The amount of 5-HT release from the control small intestine, lung, aorta and heart in anaphylaxis was $0.10 \pm 0.01,0.08 \pm 0.01,1.22 \pm 0.63$ and 0.12 上. $0.00 \mu \mathrm{g} / \mathrm{g}$, respectively. When $0.01 \mathrm{mg} / \mathrm{kg}$ of Ald was given, the release from the heart was significantly increased, but that from the other tissues was not affected by Ald (Fig. 4).

3) Effects of DOCA on histamine and 5-HT release in anaphylaxis of sensitized tissues

i) Histamine release: The amount of histamine release in anaphylaxis from the small intestine, lung, aorta and heart was $0.23 \mid 0.05,1.62-0.35,3.46 .0 .67$ and $0.87 \pm$ 


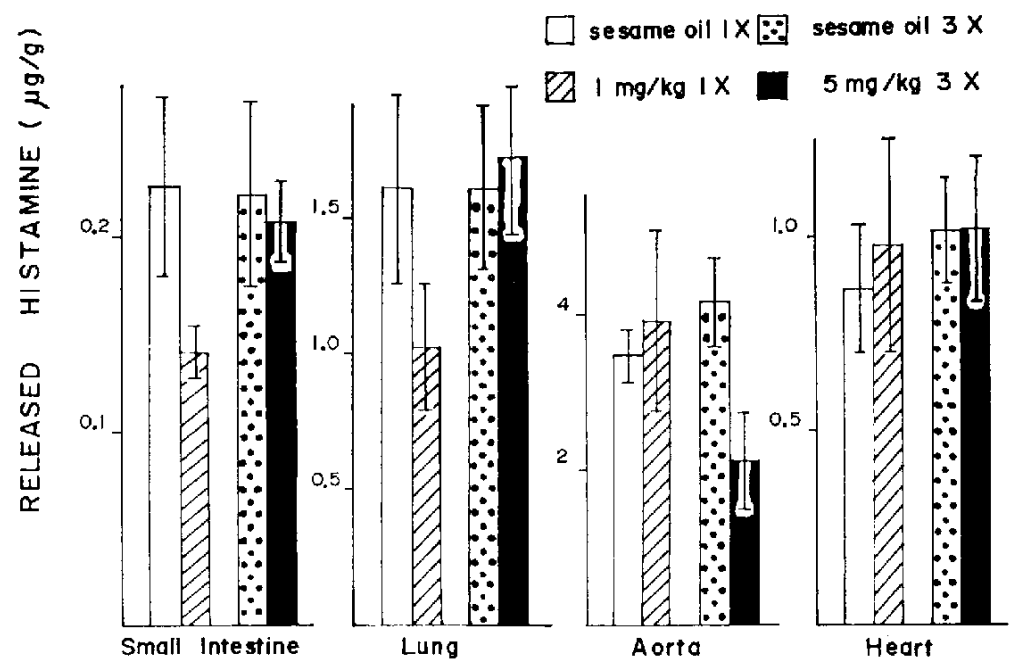

FIG. 5. Effect of DOCA on histamine release (Mean \pm S.E.) in anaphylaxis of sensitized tissues.

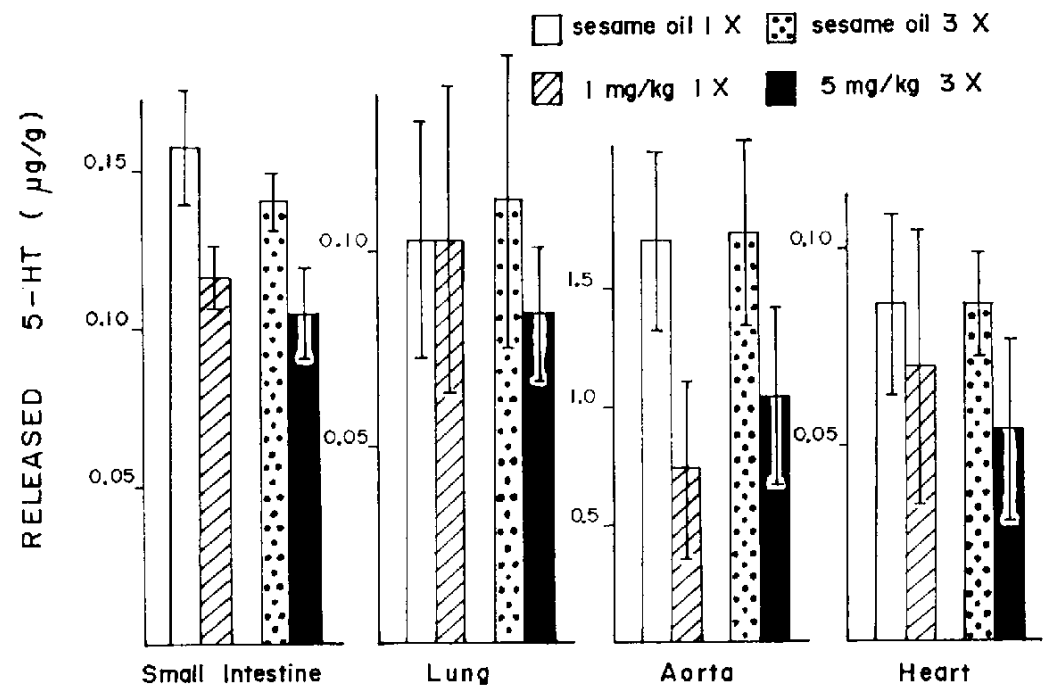

FIG. 6. Effect of DOCA on 5-HT release (Mean \pm S.E.) in anaphylaxis of sensitized tisiues.

$0.16 \mathrm{fg} / \mathrm{g}$, respectively, in the control group of a single administration of sesame oil, and $0.22 \pm 0.05,1.62 \pm 0.30,4.16 \pm 0.57$ and $1.01 \pm 0.13 \mathrm{~kg} / \mathrm{g}$, respectively, in the control group of three administrations of sesame oil.

The amount of histamine release from the anaphylactic small intestine, lung, aorta and heart after a single or for a daily $\times 3$ administrations of DOCA did not differ from that in the controls, respectively (Fig. 5).

ii) 5-HT release: The amount of 5-HT release in anaphylaxis from the small intestine lung, aorta and heart was $0.16 \pm 0.02,0.10 \pm 0.03,1.71+0.38$ and $0.09 \pm 0.02 \mu \mathrm{g} / \mathrm{g}$, respec- 
tively, in the control group of one time administration of sesame oil, and $0.14 \pm 0.01,0.11 \pm$ $0.04,1.74 \perp 0.39$ and $0.09 \pm 0.01 \mu \mathrm{g} / \mathrm{g}$, respectively, in the control group when three administrations of sesame oil were given.

The amount of 5-HT release from the anaphylactic small intestine, lung, aorta and heart after a single or daily $\times 3$ administration of DOCA did not differ from the controls, respectively (Fig. 6).

\section{DISCUSSION}

In our previous work (1), we investigated mediators released from anaphylactic tissues of sensitized guinea pigs, and reported that active sensitization would be more suitable than a passive one for the determination of the exact release of the mediators, since in the latter, a large amount is released spontaneously into antiserum Tyrode solution during a passive scnsitization procedure. Therefore, active sensitization was used exclusively in the present experiment.

There are many reports that histamine release from tissues by sinomenine, a histamineliberating agent, is inhibited by glucocorticoids. Thus Sanuki (4), Ono (5), Irino (6) and Kanai (7) reported that histamine release, induced by sinomenine, was suppressed by corticoids. And Yamasaki and Yamamoto (8) reported that decrease in rat skin histamine after dextran administration was inhibited by corticoids, and that this inhibitory action was proportional to their antiinflammatory actions. The administration of ACTH and cortisone failed to protect guinea pigs from fatal anaphylaxis (9), but Feinberg and Malkiel (10) and Mendes (11) reported that these hormones markedly protected the sensitized guinea pigs from experimental asthma, produced by inhalation of the antigen. Thus clinical efficacy of glucocorticoids for asthmatic patients was experimentally supported. To the authors' knowledge, however, there are no reports on the effect of corticoids on mediators released in in vitro anaphylaxis. It was anticipated from the aforementioned reports that histamine release (observed in the present in vitro anaphylaxis) would be strongly inhibited by Dex, but the fact that mineralocorticoid Ald would significantly decrease histamine release in anaphylaxis was hardly anticipated. According to Telford and West (12), histamine content in the skin and small intestine of the rat was markedly reduced by repeated administrations of glucocorticoid, but no effect was exerted by mineralocorticoids. Hicks and West (13) and Hicks (14), who obtained similar results, considered that corticoids regulated tissue reserve histamine. Also Kovacs (15) reported that histamine contents in various tissues of the guinea pig were decreased by repeated administration of cortisone, but increased by metyrapone, a corticoid inhibitor. As already described in various reports, mineralocorticoids have no effect on the histamine release by a histamine-liberating substance or on histamine content in tissue. The present experiment, however, demonstrated that a mineralocorticoid Ald inhibited histamine release in anaphylaxis. This fact, together with its eosinophlis diminishing activity, liver glycogen deposition activity, and activity to enhance resistance to cold stress (16) clearly distinguishes Ald from DOCA. As for the mechanism underlying the reduction by corticoid of histamine release in an- 
aphylaxis, the following possibliities have to be considered in addition to the above mentioned decrease in tissue histamine content: Lowered binding activity of the tissue histamine (17), suppression to the recovery rate of tissue histamine after its depletion (18), and stabilizing effect on the cell membrane (7). In the present experiment, the effect on the antibody may have been negligible, since Dex and Ald were given $24 \mathrm{hr}$ and $3 \mathrm{hr}$ before sacrifice, respectively. As for histamine contents and histidine decarboxylase activities in various tissues used in the present experiment, investigation is now under way. As for 5-HT, Telford and West (12) stated that the content in the skin and small intestine of the rat was reduced by repeated administration of glucocorticoid but not affected by mineralocorticoid, and that 5-hydroxytryptophan decarboxylase activity in the liver and kidney of the rat was not influenced even by a glucocorticoid. In the prsesent experiment, significant decrease in 5-HT release was observed only in the Dex-given group. The release of 5-HT is considered spontaneous and unrelated to anaphylaxis (1). The reduction in 5-HT release after Dex administration is thus attributed to inhibition of the spontaneous release.

\section{REFERENCES}

1) Kurihara, N. and Shibata, K.: Japan. J. Pharmacol. 23, 853 (1973)

2) Shore, P.A., Burkhulter, A, And Cohn, V.H. Jr.: J. Pharmacol, exp. Ther. 127, 182 (1959)

3) Udenfriend, S., Weissbach, H. and Clark, C.T.: J. hiol. Chem. 215337 (1955)

4) Sanuki, K.: Japan. J. Pharmacol. 6, 69 (1957)

5) ONO, H.: Folia pharmacol. japon. 54, 407 (1958) (in Japanese)

6) Irino, S.: Acta med. Okayama 12, 93 (1958)

7) KanaI, H.: Okayama Igakkai Zasshi 79, 791 (1967) (in Japanese)

8) Yamasaki, H. And Yamamoto, T.: Japan. J. Pharmacol. 13, 223 (1963)

9) MaLKILL, S.: J. Immunol. 66, 379 (1951)

10) Feinderg, S.M. and Malkiel, S.: Proc. Soc. exp. Biol. Med. 81, 104 (1952)

11) MENDES, E.: Acta allerg. (Kbh.) 11, 181 (1957)

12) Tflford, J.M. And West, G.B.: Brit. J. Pharmacol. 15, 532 (1960)

13) Hicks, R. and West, G.B.: Nature (Lond.) 181, 1342 (1958)

14) Hicks, R.: Brit. J. Pharmacol. 25, 664 (1965)

15) Kovacs, E.M.: Brit. J. Pharmacol. 24, 574 (1965)

16) TAsaks, S.: Clinical Endocrinology p, 199, Chugai lgaku Sha, Tokyo (1961) (in Japanese)

17) Schayer, R.W., Smiley, R.L. ANd Dayis, K.J.: Proc. Soc. exp. Biol. Med. 87, 590 (1954)

18) Goth, A., Allman, R.M., Meritt, B.C. and Holman, J.: Proc. Soc. exp. Biol. Med. 78, $848(1951)$ 